\title{
ANALISIS KESUKSESAN PENERAPAN SISTEM INFORMASI E-SPT PAJAK PENJUALAN (PPN) TERHADAP KEPATUHAN PAJAK PADA KANTOR PELAYANAN PAJAK MADYA A DAN KANTOR PELAYANAN PAJAK MADYA B
}

\author{
Etik Ipda Riyani \\ Fakultas Ekonomi Universitas Terbuka \\ riyani.ipda@yahoo.com
}

\begin{abstract}
ABSTRAK
Etik Ipda Riyani: Penelitian ini bertujuan untuk menganalisis hubungan kesuksesan penerapan sistem informasi e-SPT Pajak Penjualan (e-SPT PPN) terhadap kepatuhan pajak. Adapun model yang digunakan pada penelitian adalah model kesuksesan sistem informasi updated D\&M IS Success Model. Model ini mendasarkan pada 6 pengukuran kesuksesan informasi yaitu kualitas sistem (System Quality), kualitas informasi (Information Quality), kualitas pelayanan (Service Quality), minat pengguna (Intention to Use), kepuasan pengguna (User Satisfaction), dan kepatuhan pajak. Populasi dari penelitian ini adalah seluruh Wajib Pajak yang berbentuk badan dan terdaftar di Kantor Pelayanan Pajak Madya A dan B. Peneliti menggunakan simple random sampling dalam penarikan sampel. Alat analisis yang digunakan dalam penelitian ini adalah Analisis Jalur (Path Analysis).

Hasil penelitian menunjukkan kesuksesan implementasi sistem informasi e-SPT PPN dengan dimensi System Quality, Information Quality, dan Service Quality, Intention to Use dan User Satisfaction berpengaruh terhadap Kepatuhan Pajak.
\end{abstract}

Etik Ipda Riyani: This study aimed to analyze the relationship between the success of the implementation of the information system e-SPT Sales Tax (e-SPT PPN) to tax compliance. The model used in the study was the model of success of information systems updated D \& M IS Success Model. This model is based on six measures of success is the quality information system (System Quality), the quality of information (Information Quality), quality of service (Service Quality), user interest (Intention to Use), the satisfaction of users (User Satisfaction), and tax compliance. The population of this research is all taxpayer is incorporated and registered in Madya Tax Office A and B. Researchers using simple random sampling in the sampling. The analytical tool used in this study were Path Analysis (Path Analysis).

The results showed the successful implementation of the information system e-SPT PPN with dimensions System Quality, Information Quality, and Service Quality, Intention to Use and User Satisfaction effect on Tax Compliance.

Key words: the success of information systems, e-SPT VAT, tax compliance

\section{LATAR BELAKANG}

Era globalisasi saat ini menuntut kecepatan arus informasi. Hal ini mendorong perusahaan untuk menggunakan teknologi informasi sebagai pengolah dan penyedia informasi. Penggunaan teknologi komputer memungkinkan perusahaan untuk menerapkan sistem informasi yang dapat memberikan informasi-informasi yang akurat, relevan dan tepat waktu. Penerapan suatu sistem informasi dalam organisasi selain harus didukung teknologi informasi juga kemampuan yang baik dari pengguna sistem. Penerapan sistem informasi di perusahaan sangat diharapkan berhasil atau sukses dalam pelaksanaannya. Kesuksesan suatu sistem informasi dapat didefinisikan sebagai suatu tingkat dimana sistem informasi memberikan kontribusinya kepada organisasi dalam pencapaian tujuannya (Kim et.al 1998).

Banyak penelitian telah dilakukan mengenai bagaimana mengukur kesuksesan sistem informasi. Salah satu penelitian yang terkenal adalah penelitian DeLone dan McLean (1992). Model kesuksesan sistem informasi yang dikembangkan oleh DeLone and McLean (1992) yang dikenal dengan D\&M IS Success Model ini cepat mendapatkan tanggapan. Salah satu sebabnya karena model tersebut merupakan model yang sederhana tetapi dianggap cukup valid. Model ini merupakan suatu model yang digunakan untuk mengukur faktor-faktor yang mempengaruhi kesuksesan sistem informasi dalam suatu organisasi dengan menggunakan enam dimensi pengukuran yaitu: 1) Kualitas Informasi (Information Quality), 2) Kualitas Sistem (Sistem Quality), 3) Pemakaian (Use), 4) Kepuasan Pemakai (User Satisfaction), 5) Dampak Individual (Individual Impact), dan 6) Dampak Organisasional (Organizational Impact). Pada tahun 2003, DeLone dan McLean memperbarui modelnya dengan 1) memasukkan dimensi Kualitas 
Pelayanan (Service Quality), 2) menggabungkan dimensi Dampak Individual (Individual Impact) dan Dampak Organisasi (Organizational Impact) menjadi Manfaat-manfaat Bersih (Net Benefits), 3) menambahkan dimensi Minat Pengguna (Intention to use). Model ini dikenal dengan updated D\&M IS Success Model. Selain DeLone dan McLean, Hamilton dan Chervany (1981) mengusulkan bahwa satusatunya faktor penentu keberhasilan suatu sistem informasi adalah kepuasan pengguna.

Di bidang perpajakan, pajak memiliki peranan penting dalam kehidupan bernegara khususnya dalam melanjutkan pembangunan karena pajak merupakan sumber pendapatan negara untuk membiayai sebagian besar pengeluaran negara.

Dalam hal ini, Direktorat Jenderal Pajak (DJP) mengemban tugas untuk mengoptimalkan target penerimaan dari sektor pajak dalam APBN. Dengan demikian, untuk mengoptimalkan pendapatan negara yang bersumber dari pajak, maka dilakukan berbagai perubahan pada sektor perpajakan terutama yang bersifat fundamental. Langkah pemerintah yang merupakan perubahan mendasar di bidang perpajakan adalah melalui reformasi perpajakan (tax reform). Reformasi perpajakan terdiri dari reformasi kebijakan dan administrasi. Salah satu dari program reformasi administrasi yang sedang dilakukan pemerintah melalui DJP sejak tahun 2002 adalah modernisasi administrasi perpajakan. Perubahan-perubahan yang dilakukan dan merupakan karakteristik modernisasi administrasi perpajakan antara lain adalah business process serta teknologi informasi dan komunikasi (meliputi penerapan full automation misalnya penerapan $e$-system perpajakan, Sistem Informasi Direktorat Jenderal Pajak/SIDJP). $e$-SPT adalah aplikasi (software) yang dibuat oleh DJP untuk digunakan oleh Wajib Pajak untuk kemudahan dalam menyampaikan Surat Pemberitahuan (SPT). E-SPT PPN merupakan contoh dari implementasi sistem informasi perpajakan (e-system) dimana Wajib Pajak dapat memenuhi kewajiban perpajakannya dengan menggunakan teknologi informasi berbasis komputer.

Kontribusi pajak dalam mendanai pengeluaran negara terus meningkat sehingga membutuhkan dukungan selain berupa fasilitas pelayanan dari DJP juga peningkatan kepatuhan dari Wajib Pajak untuk memenuhi kewajiban perpajakannya secara jujur dan bertanggung jawab. Kepatuhan perpajakan menurut Nurmantu (2003) yaitu suatu keadaan dimana Wajib Pajak memenuhi semua kewajiban perpajakan dan melaksanakan hak perpajakannya. Pada kenyataannya, di Indonesia menunjukkan tingkat kepatuhan pajak yang masih rendah. Hal ini dapat dilihat dari belum optimalnya penerimaan pajak yang tercermin pada tax ratio. Tax ratio atau rasio pajak merupakan perbandingan antara jumlah penerimaan pajak dibandingkan dengan Produk Domestik Bruto (PDB) suatu negara. Rasio ini digunakan untuk menilai tingkat kepatuhan pembayaran pajak oleh masyarakat dalam suatu negara. Logikanya, semakin tinggi nilai tax ratio-nya maka semakin patuh Wajib Pajak dalam melakukan kewajiban perpajakannya di negara tersebut. Menurut Gunadi (2008), tax ratio secara umum berkisar 15 persen 20 persen di negara berkembang dan 30 persen atau lebih di negara maju.

Berdasarkan data pada nota keuangan dan RAPBN tahun 2011, bahwa tax ratio selama periode 2005 sampai dengan 2010 di Indonesia yaitu sebesar 11\% - 13,3\% dapat dilihat pada Tabel 1.

Tabel 1. Tax Ratio (periode 2005-2010, dalam prosentase)

\begin{tabular}{|c|c|}
\hline Tahun & Tax Ratio (\%-tase) \\
\hline 2005 & 12,5 \\
\hline 2006 & 12,3 \\
\hline 2007 & 12,4 \\
\hline 2008 & 13,3 \\
\hline 2009 & 11,0 \\
\hline 2010 & 11,9 \\
\hline
\end{tabular}

Sumber: Nota Keuangan dan RAPBN 2011

Berdasarkan data tersebut, tax ratio Indonesia memang cukup rendah yaitu antara $11 \%$ $13,3 \%$ dan secara fluktuatif mengalami penurunan. Tax ratio yang rendah mengindikasikan pemungutan pajak yang belum optimal, yang dapat disebabkan karena kepatuhan pajak yang rendah dan adanya korupsi. DJP mempunyai tugas dan kewajiban dalam meningkatkan penerimaan pajak dengan cara melakukan pembaharuan-pembaharuan dalam sistem perpajakan. Pembaharuan tersebut adalah sebagai bagian dari reformasi perpajakan (tax reform). Salah satu bentuk pembaharuan dalam sistem perpajakan tersebut adalah implementasi sistem informasi perpajakan yang berbasis teknologi, salah satunya e-SPT PPN. Sistem informasi tersebut akan memberikan layanan secara online yang memproses kerja menjadi lebih cepat, akurat dan transparan. Selain itu implementasi sistem informasi tersebut terus dilakukan untuk memudahkan, meningkatkan serta mengoptimalkan pelayanan kepada Wajib Pajak. 
Penentuan pengukuran kesuksesan suatu sistem informasi bukan merupakan suatu hal yang mudah. DeLone dan McLean (1992) melakukan studi mengenai kesuksesan sistem informasi dengan mengembangkan suatu model parsimoni (model yang lengkap tetapi sederhana) yang mereka sebut dengan nama Model Kesuksesan Sistem Informasi DeLone dan McLean (D\&M IS Success Model). Pada model tersebu tmenunjukkan bahwa kesuksesan sistem informasi dipengaruhi oleh perceived information quality dan perceived system quality merupakan prediktor yang signifikan bagi user satisfaction. User satisfaction juga merupakan prediktor yang signifikan bagi intended use dan perceived individual impact. Model Kesuksesan Sistem Informasi DeLone \& McLean (1992) dapat digambarkan sebagai berikut.

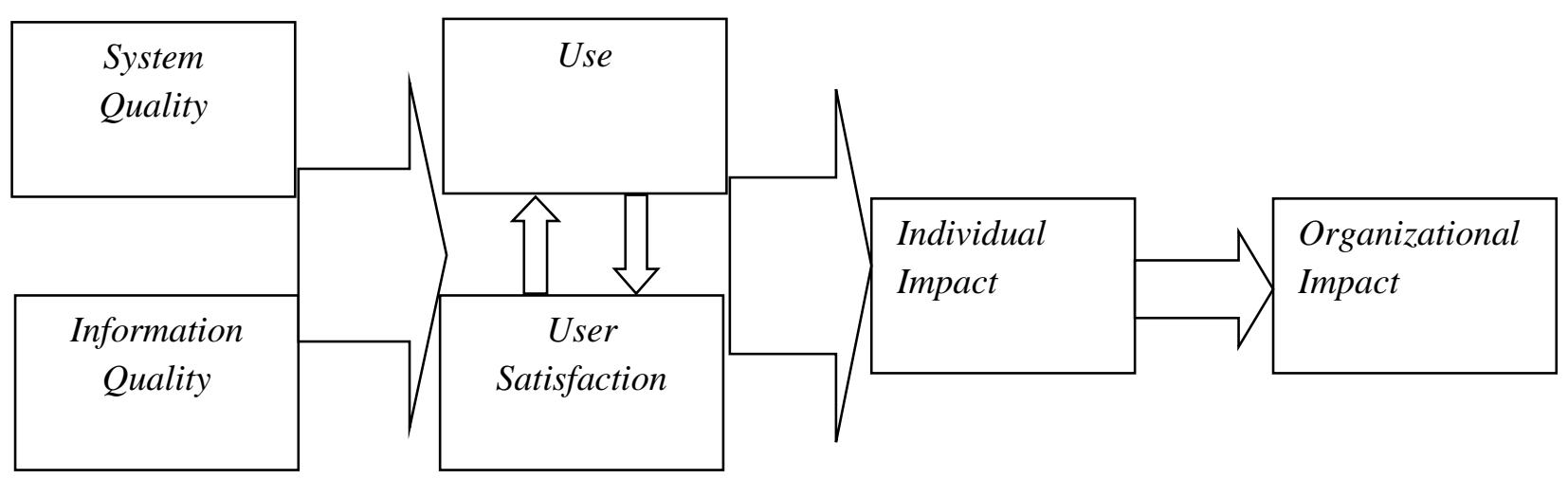

Gambar 1. Model Kesuksesan Sistem Informasi DeLone \& McLean, 1992 (D\&M IS Success Model)

Model yang dikembangkan DeLone dan McLean (1992) banyak mendapatkan tanggapan dari para peneliti baik dalam bentuk kritik maupun saran. Kritik yang paling kritis disampaikan oleh Seddon (1997). Seddon menganggap bahwa konsep proses dan kausal adalah dua konsep yang berbeda dan membingungkan untuk digabungkan.

Berdasarkan kritik dan saran tersebut, DeLone dan McLean (2003) memperbarui modelnya yaitu updated D\&M IS Success Model dengan beberapa perubahan, sebagai berikut.

a. Memasukkan dimensi kualitas pelayanan (Service Quality)

b. Menambahkan dimensi intention to use sebagai alternatif dari dimensi pemakaian (use)

c. Minat pemakai adalah suatu sikap (attitude), sedangkan pemakaian adalah perilaku (behavior). DeLone dan McLean juga berargumentasi dengan mengganti dimensi pemakaian (use) untuk memecahkan masalah yang dikritik oleh Seddon (1997) tentang model proses lawan model kausal.

Berdasarkan analisis ini, maka DeLone dan McLean (2003) mengusulkan suatu model yang diperbarui, seperti pada Gambar 2 berikut ini.

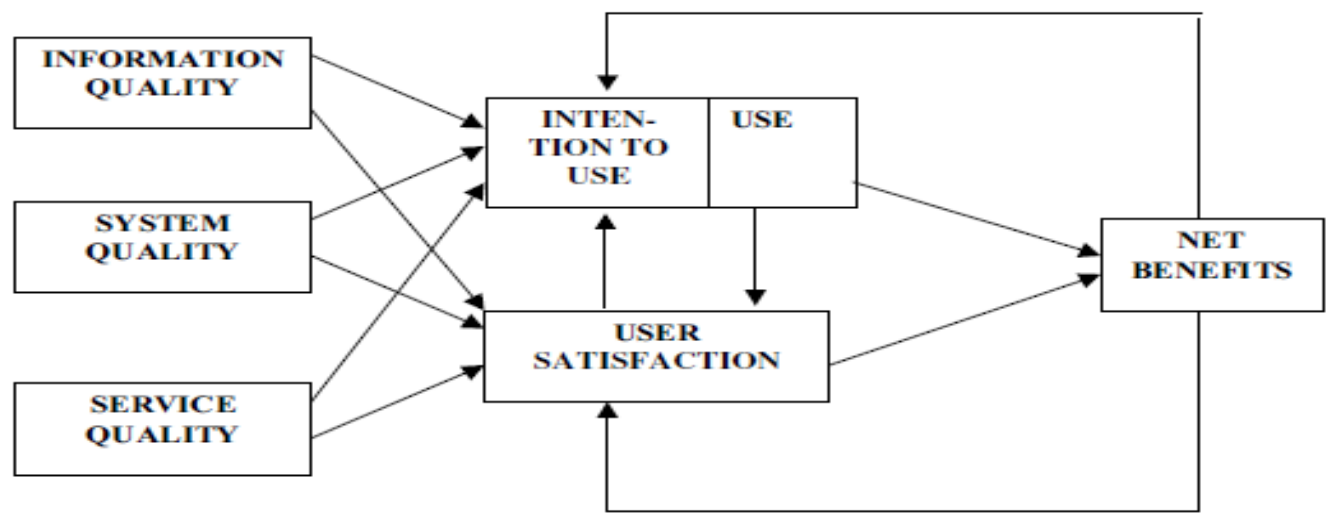

Gambar 2. Model Kesuksesan Sistem Informasi DeLone dan McLean diperbarui (2003) (updated D\&M IS Success Model)

Penelitian ini mengadopsi model penelitian DeLone dan McLean diperbarui (2003) / updated D\&M IS Success Model dan telah dimodifikasi disesuaikan dengan bidang perpajakan. Model tersebut 
menguji kesuksesan sistem informasi dengan dimensi information quality, system quality, dan service quality terhadap net benefit melalui intention to use/use dan user satisfaction.

Berdasarkan model hubungan antar variabel dapat ditarik 5 hipotesis penelitian yaitu:

1. kesuksesan implementasi sistem informasi e-SPT PPN dengan dimensi System Quality, Information Quality, dan Service Quality berpengaruh positif terhadap Intention to Use baik secara parsial maupun secara simultan.

2. kesuksesan implementasi sistem informasi e-SPT PPN dengan dimensi System Quality, Information Quality, dan Service Quality berpengaruh positif terhadap User Satisfaction baik secara parsial maupun secara simultan.

3. kesuksesan implementasi sistem informasi e-SPT PPN dengan dimensi System Quality, Information Quality, dan Service Quality berpengaruh positif terhadap Kepatuhan Pajak melalui Intention to Use

4. kesuksesan implementasi sistem informasi e-SPT PPN dengan dimensi System Quality, Information Quality, dan Service Quality berpengaruh positif terhadap Kepatuhan Pajak melalui User Satisfaction

5. Intention to Use dan User Satisfaction berpengaruh positif terhadap Kepatuhan Pajak

\section{METODE}

Data yang diperlukan dalam penelitian ini dikumpulkan melalui metode survei, yaitu dengan cara memberikan kuesioner kepada responden. Untuk memperoleh data penelitian ini dilakukan melalui proses perijinan dengan mekanisme birokrasi dari Direktorat Jenderal Pajak, serta Kantor Pelayanan Pajak (KPP) Madya A dan Kantor Pelayanan Pajak (KPP) Madya B, dimana peneliti memperoleh daftar nama dan alamat Wajib Pajak melalui wawancara secara langsung di bagian pelayanan pada kedua KPP Madya tersebut. Populasi yang dipergunakan dalam penelitian ini adalah Wajib Pajak yang berbentuk Badan yang terdaftar pada Kantor Pelayanan Pajak (KPP) Madya A dan KPP Madya B yang menggunakan e-SPT PPN pada tahun 2012. Pengambilan sampel dalam penelitian ini dilakukan secara acak sederhana (simple random sampling), dimana semua anggota populasi diberikan kesempatan yang sama untuk menjadi sampel penelitian. Berdasarkan tujuannya, penelitian ini bersifat deskriptif dan verifikatif. Metode analisis data yang digunakan pada penelitian ini adalah Analisis Jalur (Path Analysis) dengan menggunakan program SPSS versi 16 untuk analisis data verifikatifnya. Pemilihan metode Analisis Jalur (Path Analysis) dikarenakan penulis berasumsi bahwa pada penelitian ini menggunakan variabel intervening atau variabel antara. Model regresi linear dengan variabel intervening dipergunakan untuk melihat pengaruh langsung dan tidak langsung antara satu variabel terhadap variabel yang lain serta pengaruh total dari suatu variabel eksogen terhadap variabel endogen dan mencari jalur yang paling berpengaruh. Dengan kondisi tersebut, metode Analisis Jalur (Path Analysis) merupakan metode analisis yang paling cocok karena mampu melihat hubungan antar variabel, menjelaskan mengapa variabel berkorelasi, mengidentifikasi jalur penyebab suatu variabel tertentu terhadap variabel lain yang dipengaruhinya, serta menghitung besarnya pengaruh satu variabel independen exogenus atau lebih terhadap variabel dependen endogenus lainnya.

\section{HASIL DAN PEMBAHASAN}

\section{a. Uji Validitas dan Uji Reliabilitas}

Pada penelitian ini, uji validitas yang digunakan adalah korelasi Product Moment dari Pearson. Dari hasil perhitungan dengan korelasi Product Moment dari Pearson (dengan menggunakan alat bantu program Excel 2007) maka hasil pengujian validitas dari semua variabel dalam penelitian ini menunjukkan hasil valid dengan perolehan nilai diatas 0,30. Artinya, semua pernyataan yang diberikan kepada responden dinyatakan valid.

Pada penelitian ini, uji reliabilitas dilakukan dengan menggunakan metode belah dua (split half). Koefisien reliabilitas semua variabel mempunyai nilai lebih besar dari 0,70, artinya kuesioner yang digunakan reliabel. Hal ini menunjukkan bahwa semua pernyataan yang diberikan kepada responden dapat diterima.

\section{b. Analisis Jalur (Path Analysis)}

Berdasarkan hasil pengolahan data menggunakan path analysis dapat diketahui pengaruh dari masing-masing variabel penelitian

1. Hipotesis Pertama, yang menyatakan bahwa kesuksesan implementasi Sistem Informasi e-SPT PPN dengan dimensi System Quality, Information Quality, dan Service Quality berpengaruh positif terhadap Intention to Use baik secara parsial maupun secara simultan. 
Melalui uji hipotesis diperoleh hasil bahwa:

a. Dalam implementasi e-SPT PPN, kesuksesan sistem informasi dengan dimensi system quality dan information quality secara parsial berpengaruh positif terhadap intention to use, sedangkan dimensi service quality tidak berpengaruh terhadap intention to use. Dengan demikian, apabila system quality dan information quality e-SPT PPN baik, maka Wajib Pajak akan semakin sering menggunakan e-SPT PPN. Hasil penelitian ini mendukung penelitian yang dilakukan oleh DeLone dan McLean (1992), Seddon dan Kiew (1996), Rai et al., (2002), dan McGill et al., (2003).

b. Dalam implementasi e-SPT PPN, kesuksesan sistem informasi dengan dimensi system quality, information quality, dan service quality secara simultan berpengaruh terhadap intention to use. Hasil penelitian ini mendukung penelitian yang dilakukan oleh DeLone dan McLean (2003).

c. Pengaruh yang tidak signifikan diduga disebabkan sifat penggunaan sistem informasi tersebut bersifat mandatory. Dengan demikian pada implementasi e-SPT PPN, service quality tidak menjadi prediktor yang baik atas intention to use.

2. Hipotesis Kedua, yang menyatakan bahwa kesuksesan implementasi Sistem Informasi e-SPT PPN dengan dimensi System Quality, Information Quality, dan Service Quality berpengaruh positif terhadap User Satisfaction baik secara parsial maupun secara simultan.

Melalui uji hipotesis diperoleh hasil bahwa:

a. Dalam implementasi e-SPT PPN, kesuksesan sistem informasi dengan dimensi system quality dan information quality secara parsial berpengaruh positif terhadap user satisfaction, sedangkan dimensi service quality tidak berpengaruh terhadap user satisfaction. Dengan demikian, apabila sistem quality e-SPT PPN yang direpresentasikan dengan beberapa manfaat seperti kemudahan penggunaan (user friendly), kecepatan dan kemudahan akses, keamanan, fleksibilitas sistem, maka Wajib Pajak akan merasa puas. Selain itu, apabila information quality e-SPT PPN dapat memberikan informasi yang akurat, tidak bias, tepat waktu, terkini, lengkap, sesuai dengan kebutuhan pengguna (user), serta menyajikan format informasi yang baik dan jelas sehingga memudahkan pemhaman pengguna (user), maka Wajib Pajak akan merasa puas.

b. Dalam implementasi sistem e-SPT PPN, kesuksesan sistem informasi dengan dimensi system quality, information quality, dan service quality secara simultan berpengaruh terhadap user satisfaction. Hasil penelitian ini mendukung penelitian yang dilakukan oleh DeLone dan McLean (2003).

c. Pengaruh yang tidak signifikan diduga disebabkan sifat penggunaan sistem informasi tersebut bersifat mandatory. Dengan demikian pada implementasi e-SPT PPN, service quality tidak menjadi prediktor yang baik atas User Satisfaction.

3. Hipotesis Ketiga, yang menyatakan bahwa kesuksesan implementasi sistem informasi e-SPT PPN dengan dimensi System Quality, Information Quality, dan Service Quality berpengaruh positif terhadap Kepatuhan Pajak melalui Intention to Use.

Melalui uji hipotesis diperoleh hasil bahwa:

Pada implementasi e-SPT PPN, besarnya pengaruh total kesuksesan implementasi sistem informasi perpajakan (e-system) dengan dimensi System Quality, Information Quality, dan Service Quality terhadap Kepatuhan Pajak adalah 33,72\% yang terdiri dari pengaruh langsung kesuksesan implementasi sistem informasi perpajakan (e-system) dengan dimensi System Quality, Information Quality, dan Service Quality terhadap Kepatuhan Pajak 26,17\% dan pengaruh tidak langsung dimana kesuksesan implementasi sistem informasi perpajakan (e-system) dengan dimensi System Quality, Information Quality, dan Service Quality terhadap Kepatuhan Pajak melalui Intention to Use adalah sebesar 7,55\%.

Hal ini berarti pada implementasi sistem e-SPT PPN, dengan adanya variabel Intention to Use akan meningkatkan pengaruh kesuksesan implementasi sistem informasi perpajakan (e-system) dengan dimensi System Quality, Information Quality, dan Service Quality terhadap Kepatuhan Pajak. Sehingga dapat dikatakan bahwa penggunaan variabel Intention to Use sebagai variabel intervening adalah tepat.

4. Hipotesis Keempat, yang menyatakan bahwa kesuksesan implementasi sistem informasi e-SPT PPN dengan dimensi System Quality, Information Quality, dan Service Quality berpengaruh positif terhadap Kepatuhan Pajak melalui User Satisfaction. 
Melalui uji hipotesis diperoleh hasil bahwa:

Pada implementasi e-SPT PPN, besarnya pengaruh total kesuksesan implementasi sistem informasi perpajakan (e-system) dengan dimensi System Quality, Information Quality, dan Service Quality terhadap Kepatuhan Pajak adalah 30,01\% yang terdiri dari pengaruh langsung kesuksesan implementasi sistem informasi perpajakan (e-system) dengan dimensi System Quality, Information Quality, dan Service Quality terhadap Kepatuhan Pajak 26,17\% dan pengaruh tidak langsung dimana kesuksesan implementasi sistem informasi perpajakan (e-system) dengan dimensi System Quality, Information Quality, dan Service Quality terhadap Kepatuhan Pajak melalui User Satisfaction adalah sebesar 3,84\%.

Hal ini berarti pada implementasi e-SPT PPN dengan adanya variabel User Satisfaction akan meningkatkan pengaruh kesuksesan implementasi sistem informasi perpajakan (e-system) dengan dimensi System Quality, Information Quality, dan Service Quality terhadap Kepatuhan Pajak. Sehingga dapat dikatakan bahwa penggunaan variabel User Satisfaction sebagai variabel intervening adalah tepat.

5. Hipotesis Kelima, yang menyatakan bahwa Intention to Use dan User Satisfaction berpengaruh positif terhadap Kepatuhan Pajak.

Melalui uji hipotesis diperoleh hasil bahwa:

Dalam implementasi e-SPT PPN, Intention to Use dan User Satisfaction berpengaruh positif terhadap Kepatuhan Pajak. Jika Wajib Pajak sebagai pengguna sistem merasakan atas manfaat sistem yang digunakan maka Wajib Pajak tersebut akan memiliki minat untuk melakukan penggunaan sistem yang berulang-ulang, dan menandakan bahwa Wajib Pajak merasa puas atas penggunaan sistem tersebut. Dengan demikian, meningkatnya Intention to Use dan User Satisfaction akan berdampak terhadap peningkatan Kepatuhan Pajak.

\section{KESIMPULAN}

1. Kesuksesan implementasi sistem informasi e-SPT PPN dengan dimensi System Quality, Information Quality, dan Service Quality melalui Intention to Use dan User Satisfaction berpengaruh terhadap Kepatuhan Pajak.

2. Pada implementasi sistem e-SPT PPN, dari ke-3 dimensi kesuksesan implementasi sistem informasi yang berpengaruh terhadap intention to use dan user satisfaction adalah dimensi system quality dan information quality. Hanya variabel service quality yang tidak berpengaruh signifikan terhadap intention to use dan user satisfaction. Hal ini dimungkinkan terjadi karena penggunaan e-system perpajakan bersifat wajib dan mandatory sehingga wajib pajak tidak mempertimbangkan variabel tersebut.

3. Variabel service quality tidak menjadi prediktor yang baik atas intention to use dan user satisfaction untuk implementasi e-SPT PPN. Hasil ini mendukung penelitian Livari (2005) dan penelitian Mc Gill et al. (2003) yang keduanya hanya dapat membuktikan sebagian dalam pengujian model kesuksesan dalam pengembangan sistem informasi dengan model DeLone and McLean.

4. Kesuksesan implementasi sistem e-SPT PPN dengan dimensi System Quality, Information Quality, dan Service Quality melalui Intention to Use dan User Satisfaction berpengaruh terhadap Kepatuhan Pajak.

\section{DAFTAR PUSTAKA}

Bailey, J.E., and S.W. Pearson, 1983, "Development of a Tool for Measuring and Analyzing Computer User Satisfaction", Management Science. 29 (May).

DeLone, W.H., and E.R. McLean, 1992, "Information System Success: The Quest for The Dependent Variable, Information System Research", (3:1) pp 60-95.

DeLone, W.H. and E.R. Mc Lean, 2003, "The DeLone and McLean Model of Information System Success: A Ten Year Update", Journal of Management Information (19:4). pp 9-30.

Doll, W.J., and Torkzadeh G, 1988, "The Measurement of End-user Computing Satisfaction", MIS Quarterly (12:2): $159-174$ 
Hamilton, S., and Chervany, N.L, 1981, "Evaluating Information System Effectiveness Part 1: Comparing Evaluation Approaches", MIS Quarterly (5:3), 56-69.

Kim, Changki, K Suh., and J. Lee, 1998, "Utilization and User Satisfaction in End User Computing, A Task Contingent Model", Information Resources Management Journal. Fall.p. 11-24.

Laudon, Kenneth C., and Jane P. Laudon, 2000, "Organization and Technology in The Networked Enterprise", Management Information System. Six Edition. International Edition.

Nurmantu, Safri, 2003, “Pengantar Perpajakan”, edisi 2. Jakarta : Granit.

Seddon, P., B, 1997, " A Respecification and Extension of The DeLone and McLean's Model of Information Success." Information System Research, Vol. 8, No. 3.

Gunadi, 2008, "Problematika Peningkatan Tax Ratio", Harian Kompas, 7 Januari 2008. 